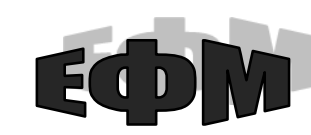

http://efm.vsau.org/

ЕКОНОМІКА ТА ЕФЕКТИВНІСТЬ

ВИРОБНИЧО-ГОСПОААРСЬКОЇ АІЯЛЬНОСТІ

\section{УАК 330:005.52:005.334:388.432 \\ НЕОБХІДНІСТЬ ВИКОРИСТАННЯ АІАГНОСТИКИ В СИСТЕМІ АНТИКРИЗОВОГО МЕНЕДЖМЕНТУ ПІДПРИЕМСТВ ГАЛУЗІ АПК ${ }^{\odot}$}

Н.Ю. ФІЩУК, кандидат сільськогосподарських наук, доцент кафедри аграрного менеджнменту, Вінницький національний аграрний університет (м. Вінниця)

У статті розглянуто питання сутності та об'єктивної необхідності використання підходів антикризового менеджменту в сучасних умовах діяльності підприємств аграрної сфери. Визначено необхідність проведення антикризового моніторингу стану підприємств та діагностики як складової, щзо його забезпечує.

Розглянуто найбільш розповсюджені моделі прогнозування кризового стану підприємств, особливості їх використання та недоліки. Досліджено можливість використання деяких зарубіжних та вітчизняних моделей в діагностуванні кризового стану підприємств з метою недопущення банкрутства.

Встановлено, щз моделі прогнозування банкрутства, які найчастіше застосовують у практииі антикризового менеджменту економічно розвинених країн світу, в умовах національної економіки не завжди дозволяють отримати об'єктивну та повну інформацію щзодо стану підприємства, вчасно виявити небажані відхилення та оцінити ймовірність банкрутства.

Визначено необхідність адаптащіі методик прогнозування ймовірності потрапляння підприємства в зону критичного ризику до ситуачії в національній економіці, існуючих ризиків, особливостей діяльності, специфіки обліку і звітності на підприємствах Украӥни в ијілому й аграрної сфери, зокрема.

Ключові слова: антикризовий менеджмент, антикризовий моніторинг, криза, банкрутство, ризики, діагностика, моделі прогнозування банкрутства, превентивні заходи, консорціум.

Табл.: 4. Літ.: 14.

\title{
THE NECESSITY FOR DIAGNOSTICS USING IN THE SYSTEM OF ANTICRISIS MANAGEMENT OF AGRICULTURAL INDUSTRY ENTERPRISES
}

FISHCHUK Natalia, Associate Professor of the Department of Agrarian Management, Vinnytsia National Agrarian University (Vinnytsia)

The publication considers the issue of the nature and objective necessity of using approaches of crisis management in modern conditions of activity of enterprises in

\footnotetext{
${ }^{\circledR}$ Н.Н. ФІЩУК, 2019
} 


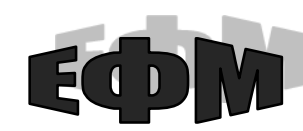

http://efm.vsau.org/

agricultural sector. The need for anti-crisis monitoring of the state of enterprises and diagnostics as its supporting component has been determined.

The most common models for forecasting the crisis state of enterprises, especially their application and disadvantages, are considered. The possibility of using some foreign and domestic models in diagnosing the crisis state of enterprises in order to prevent bankruptcy is investigated.

It has been established that the bankruptcy prediction models most widely used in the practice of crisis management in the economically developed countries of the world do not always allow obtaining objective and complete information about the state of the enterprise in time, identify undesirable deviations and assess the probability of bankruptcy.

The need to adapt the methods of forecasting the probability of an enterprise getting into a critical risk zone to the situation in the national economy, existing risks, business specifics, the specifics of accounting and reporting at enterprises of Ukraine as a whole and specifically the agro-industrial sector has been established.

Key words: crisis management, crisis monitoring, crisis, bankruptcy, risks, diagnostics, bankruptcy forecasting models, preventive measures, consortium.

Tabl.: 4. Ref.: 14.

\title{
НЕОБХОДИМОСТЬ ИСПОЛЬЗОВАНИЯ ДИАГНОСТИКИ В СИСТЕМЕ АНТИКРИЗИСНОГО МЕНЕДЖМЕНТА ПРЕДПРИЯТИЙ АПК
}

\author{
ФИЩУК Наталия Юрьевна, \\ кандидат сельскохозяйственных наук, \\ доцент кафедры аграрного менеджсмента, \\ Винницкий национальный аграрный университет
} (2.Винница)

В публикации рассматривается вопрос сущзности и объективной необходимости использования подходов антикризисного менеджмента в современных условиях деятельности предприятий аграрной отрасли. Определена необходимость проведения антикризисного мониторинга состояния предприятий и діагностики в качетве его обеспечивающей составляющей.

Рассмотрены наиболее распространенные модели прогнозирования кризисного состояния предприятий, особенности их применения и недостатки. Исследована возможность использования некоторых зарубежных и отечественных моделей в диагностировании кризисного состояния предприятий с целью недопущения банкротства.

Установлено, что модели прогнозирования банкротства, наиболее широко используемые в практике антикризисного менеджмента экономически развитых стран мира, в условиях национальной экономики не всегда позволяют получить объективную и полную информацию относительно состояния предприятия, вовремя выявить нежелательные отклонения и оценить вероятность банкротства.

Установлена необходимость адаптации методик прогнозирования вероятности попадания предприятия в зону критического риска к ситуации в национальной экономике, существующим рискам, особенностям деятельности, специфике учёта и отчётности на предприятиях Украини в ичелом и конкретно отрасли АПК. 


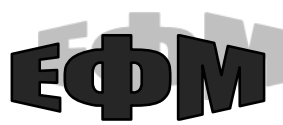

http://efm.vsau.org/

Ключевые слова: антикризисный менеджмент, антикризисный мониторинг, кризис, банкротство, риски, диагностика, модели прогнозирования банкротства, превентивные меры, консорциум.

Табл.: 4. Лит.: 14.

Постановка проблеми. Кризові явища час від часу відбуваються у будь-якому суспільстві, загрожуючи його існуванню, цілісності і стабільності. Тим більш очевидно, що криза здатна порушити рівновагу у будь-якій галузі економіки країни та на окремому підприємстві. Не завершивши перебудову і все ще перебуваючи у трансформаційному стані, країни пострадянського простору значно важче долають нинішню кризу, яка розпочалась у світі ще у 2007 році. Значний вплив на діяльність вітчизняних підприємств справляють глобальна фінансово-економічна криза, політична нестабільність, недосконалість законодавства та недостатній рівень державної регуляторної політики. Щоб запобігти негативному впливу факторів ризику як з боку зовнішнього, так і внутрішнього середовища, необхідний перегляд i удосконалення особливих інструментів і підходів антикризового управління, які застосовуються в практиці господарської діяльності. Проведення постійного антикризового моніторингу підприємства при цьому є ключовим аспектом.

Необхідність формування системи антикризового управління діяльністю підприємств, проведення діагностики як його специфічної функції, визначення прийнятності різних моделей діагностування, потреба у розробці антикризових підходів і стратегій розвитку сільськогосподарських підприємств зумовили актуальність обраної теми.

Аналіз останніх досліджень і публікацій. Проблематика виходу з кризових ситуацій і вивчення чинників їх виникнення була i залишається актуальною як на рівні державного управління, так і на рівні галузей та окремих підприємств. Напрацьовано величезний обсяг теоретичного та прикладного матеріалу, однак тема криз й антикризового управління залишається в полі зору зарубіжних і вітчизняних вчених. Вагомий внесок у вирішення та розробку цих питань зробили вчені зарубіжжя: Альтман Е., Бівер У., Майєр Джеральд М., Спрінгейт Г., Таффлер Р., Тішоу Г., Ліс Р., Фулмер та багато інших. Завдячуючи їх дослідженням, визначено параметри фінансової безпеки та зони ризику підприємств, показники для прогнозування ймовірності банкрутства та їх вагові коефіцієнти.

Проблеми діагностики фінансово-економічного стану українських підприємств, розробки методик та їх імплементації, адаптації зарубіжних методик, визначення критеріїв у прогнозуванні банкрутства знайшли своє відображення у наукових працях відомих вітчизняних вчених, зокрема Терещенка О.О. [11, 12], Матвійчука А.А. [5], Скібіцького О.М. [10], Муляр Т.С. [7], Янковець Т.М. [13], Мазура В.А. [4], Власюка В.С. [1], Воронкової Т.С. [2], Ракосій П.В. [9 ] та багатьох інших.

Не дивлячись на значний обсяг теоретичних напрацювань та набутого досвіду діяльності підприємств в кризових умовах, формування ефективної системи антикризового менеджменту, проведення антикризового моніторингу й діагностики як складової, що забезпечує його, не втратили своєї актуальності. Особливої гостроти ця проблема набула в аграрних підприємствах України, що має певні об'єктивні підстави. У першу чергу, це пояснюється недостатністю узагальнених методичних підходів, рекомендацій і критеріїв, в достатній мірі адаптованих до специфічних умов 
вітчизняної аграрної економіки та прийнятих систем обліку і звітності. Численні питання діагностики стану підприємств аграрної сфери, розробки методик, які б забезпечували об’єктивність отриманих результатів, потребують додаткових досліджень.

Формулювання цілей статті. Мета статті полягає в обгрунтуванні необхідності здійснення діагностики як базової функції антикризового управління; апробації використання найбільш поширених зарубіжних та вітчизняних методик діагностики кризового стану, оцінюванні можливості їх застосування в умовах діяльності сільськогосподарських підприємств.

Виклад основного матеріалу дослідження. Для України сільське господарство є важливою складовою фінансової та продовольчої безпеки держави, що гарантує подальший економічний розвиток країни. Сучасне сільське господарство долає складний шлях розвитку, це одна з найважливіших і ризикованих галузей економіки нашої країни. Україна має потужний агропромисловий потенціал та значні перспективи його розвитку в майбутньому. В першу чергу, це забезпечується сприятливими природно-кліматичними умовами і якісними грунтами, які дають можливість ефективно розвивати сільськогосподарське виробництво. В Україні аграрний сектор виконує багатофункціональну місію - економічну, соціальну, екологічну. В аграрному секторі економіки формується близько 17\% ВВП (третє місце за часткою ВВП країни), він є одним з основних бюджетоутворюючих та експортоорієнтованих секторів національної економіки. За результатами 2017 року індекс обсягу виробництва продукції сільського господарства становив 102,6; було отримано 279 млрд грн чистого доходу від реалізації продукції; рентабельність операційної діяльності становила $42 \%$; закінчили рік із прибутками $82 \%$ підприємств, а частка збиткових підприємств скоротилась із 11\% (2016 р.) до 8\% (2017 р.). Загалом, сільське господарство залишається практично єдиною галуззю економіки, яка протягом тривалого часу забезпечує позитивне зовнішньоторговельне сальдо [3].

I все ж результати діяльності сільськогосподарських підприємств не відповідають ресурсному потенціалу і можливостям галузі. Економічно-соціальна ситуація залишається складною i напруженою. Причинами кризового стану підприємств практично усіх галузей та секторів економіки України є не лише вплив зовнішніх факторів: зниження платоспроможного попиту, втрата налагоджених господарських зв'язків, ринків закупівлі та збуту, суттєве збільшення цін на енергоносії, значний рівень інфляції, недосконале правове поле господарювання тощо, але і не адекватний ринковим умовам стан управління діяльністю самих суб'єктів господарювання. До факторів внутрішнього впливу, які можуть спричинити банкрутство сільськогосподарських підприємств, як правило, відносять: недостатній рівень знань про можливості передбачення кризи, недосконалу економічну політику підприємств; несвоєчасний і нерегулярний моніторинг їхньої діяльності; недостатність фінансового контролю, неадекватність i несвоєчасність реакції на зміни в навколишньому середовищі, низький техніко-технологічний рівень виробництва; недоліки в роботі фінансового і інвестиційного менеджменту, збільшення різних видів заборгованостей; недосконалу систему стратегічного планування i розвитку підприємств [4, с.7; 9, с. 110]. Як підсумовує в своїй публікації Мельниченко О.А., нинішня кризова ситуація $є$ відображенням нагромаджених внутрішніх економічних і політичних проблем, підсилених дією глобальної фінансової кризи [6, с. 3]. 


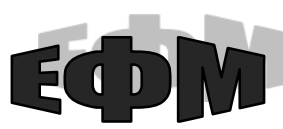

http://efm.vsau.org/

Забезпечення реалізації визначеного курсу на стійке економічне зростання України робить надзвичайно актуальними питання організації протидії кризовим явищам та відродження нормального перебігу господарювання суб'єктів підприємницької діяльності. У свою чергу, це потребує вдосконалення практики антикризового управління підприємствами, посиленої уваги до питань діагностики рівня та причин кризового стану, розробки достатньо адаптованих методик її здійснення.

Бізнес-середовище діяльності сільськогосподарських підприємств залишається в цілому несприятливим і ризикованим. У той же час, світовий досвід переконує, що жоден 3 факторів розвитку кризи, а також їх спільний вплив на підприємство, як правило, не спричиняють фатальних наслідків, їх прояву можна та потрібно протидіяти. Подвійна природа кризи означає, що вона може як зруйнувати, так і відкрити перед підприємством нові можливості, стати ключем до успіху та подальшого розвитку.

Проблема полягає і в тому, що багато управлінських працівників не знають, як діяти в умовах кризи, що змінювати у звичних підходах та методах управління для подолання кризового стану, нехтують проведенням діагностики i моніторингу діяльності підприємства. Однак саме діагностика є засобом одержання достовірної якісної інформації про реальний стан і можливості підприємства на початковій стадії кризи, основою для введення в дію особливих методів і механізмів антикризового менеджменту.

Діагностика є категорією антикризового управління, що має на меті своєчасне розпізнавання ознак і природи кризи, а також локалізацію небажаних іiі впливів. Скібіцький О.М. підкреслює iї інтегруючу функцію в антикризовій діяльності підприємства, виділяючи такі напрями ії здійснення: діагностика як елемент загального менеджменту підприємства, діагностика упереджуючого оздоровлення та діагностика кризового стану. Діагностика банкрутства - це система цільового фінансового аналізу з метою виявити та ідентифікувати параметри кризового розвитку, які можуть розбалансувати систему, знизити іiі ризикостійкість і становити загрозу банкрутства в перспективі. Специфіка іï проведення в тому, що із системи загального аналізу фінансового стану підприємства виділяється особлива група показників, відхилення яких від базових параметрів може створювати загрозу банкрутства [10, с. 154].

Таким чином, для досягнення позитивних результатів і швидкого виходу 3 кризи надзвичайно важливим $є$ передбачення можливості виникнення кризових ситуацій, визначення їх причин. На початкових етапах виявлення кризи підприємство може іiі подолати з мінімальними втратами. Відсутність вчасної і адекватної реакції може дорого коштувати підприємству і навіть поставити під сумнів його подальше існування, запустивши механізм банкрутства.

Індивідуальні особливості сільськогосподарських підприємств, їхній стан, причини і глибина кризових проявів вимагають і різних методів виходу з кризового стану. Універсальних методів боротьби з кризою не існує. Тому кожне підприємство повинне самостійно виробити свій план антикризових дій, які забезпечать його виживання.

Алгоритм дій в рамках антикризового управління можна представити у вигляді логічної послідовності кроків, які містять:

1) аналіз зовнішнього середовища і внутрішнього потенціалу конкурентних переваг підприємства для вибору стратегії його розвитку на основі прогнозування тенденцій зміни фінансового стану; 


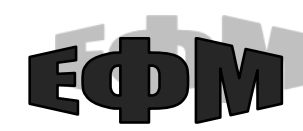

http://efm.vsau.org/

2) попередню діагностику причин виникнення кризових ситуацій в економіці й фінансах підприємства;

3) комплексну діагностику фінансово-економічного стану підприємства для встановлення методів його фінансового оздоровлення;

4) бізнес-планування фінансового оздоровлення підприємства;

5) процедури антикризового управління й контроль за їх проведенням.

Світовий досвід i практика здійснення антикризового управління на підприємствах пропонують сьогодні цілий ряд методик для здійснення діагностики банкрутства як кількісними, так і якісними методами; експрес- та поглибленим аналізом кризових явищ. Найбільш відомі і використовувані багатофакторні моделі діагностики кризового стану та прогнозування банкрутства, розроблені зарубіжними авторами: моделі на основі Z-коефіцієнтів Альтмана, Спрінгейта, Бівера, Ліса, прогнозні моделі Таффлера і Тішоу, моделі Фулмера, Беєрмана, модель рейтингового числа Сайфулліна i Кадикова, метод бальної оцінки Аргенті та інші. Зрозуміло, що ці та інші моделі розроблялись у різний час, в різних країнах і враховували зовсім інші умови діяльності підприємств, які досить сильно, а швидше, кардинально відрізняються від вітчизняних. Однак ці моделі досить активно використовують і в Україні. При цьому очевидним $\epsilon$ факт слабкої їх адаптації до національних реалій, особливостей господарювання, специфіки вітчизняної практики, галузевих умов функціонування. Цим пояснюється можливість отримання необ'єктивних, упереджених висновків, суттєвих похибок в оцінках і прогнозах [7, с. $41 ; 2$, с. $60 ; 5$, с. 20].

Серед основних недоліків використовуваних методик для оцінки фінансового стану українських підприємств найбільш часто називають: неврахування впливу факторів зовнішнього середовища, національних та галузевих особливостей об'єкту аналізу; суб'єктивність формування системи показників; ігнорування факту різної вагомості впливу окремих показників на результати аналізу; статичність значень вагових коефіцієнтів у Z-моделях, оперування виключно фінансовими показниками, в той час, коли причини кризових явищ можуть бути і поза сферою фінансів; неможливість виявити чинники, що призвели до загрози банкрутства; неможливість оцінити загальну комплексну картину діяльності тощо $[1$, с. $58 ; 7$, с. 41 ; 11 , с. $38 ; 5$, с. 20]. Крім цього, на переконання Янковець Т.М., зарубіжні моделі, як правило, не містять чітких рекомендацій щодо того, для яких підприємств їх можна застосовувати найбільш ефективно, а для яких - не варто. Спрямовані вони, насамперед, на прогнозування банкрутства великих i середніх підприємств, тому точність прогнозу щодо підприємств малого бізнесу є, щонайменше, сумнівною [13, с. 58].

Відомо, що найкращий спосіб підтвердити або ж спростувати будь-які твердження, - перевірити їх в дії. Скористаємось різними моделями діагностики банкрутства, використовуючи звітно-аналітичні дані одного із структурних підрозділів ННВК «Всеукраїнського науково-навчального консорціуму» державного підприємства «Дослідне господарство «Саливонківське» Інституту біоенергетичних культур і цукрових буряків Національної академії аграрних наук України (далі ДП «ДГ «Саливонківське»).

Всеукраїнський науково-навчальний консорціум - це нова організаційноправова структура в освіті. Створений за ініціативою керівництва Вінницького національного аграрного університету на основі вивчення та узагальнення світового досвіду, консорціум став відповіддю на сучасні виклики в освіті, науці та 
практичному господарюванні. Система освіти в Україні завжди вважалась однією із найкращих у світі, однак мала суттєвий недолік - відірваність від виробництва і науки. Це позначалось як на якості підготовлених у ЗВО фахівців, так і на прикладних аспектах наукових досліджень. Як результат, страждало виробництво, не отримуючи відповідей від науковців на свої нагальні проблеми.

До складу ННВК увійшли Вінницький національний аграрний університет, 5 коледжів, науково-дослідне господарство, центр комплексного проектування та Інститут біоенергетичних культур i цукрових буряків НААН України (У підпорядкуванні якого 8 науково-дослідних господарств). Взаємодія між ними в межах консорціуму дозволить значно покращити зв'язок між освітою, наукою i виробництвом, проявити ефект синергії, максимально використати існуючий потенціал усіх сфер [14].

Місце розташування ДП «ДГ «Саливонківське»- м. Гребінки Васильківського району Київської області. Це сучасне, високопродуктивне, прибуткове дослідне господарство, яке володіє достатніми ресурсами як для виробництва, так і для наукової діяльності. Загальна земельна площа у користуванні господарства становить 3000 га, в тому числі площа ріллі - 2548 га. Основні напрями діяльності ДП «ДГ «Саливонківське»:

- активне сприяння науковим установам Академії в роботі 3 проведення наукових дослідів, виробничої перевірки і впровадження науково-технічних розробок;

• виробництво оригінального, елітного та репродукційного насіння сільськогосподарських культур та саджанців;

- ефективне власне господарювання, як приклад застосування результатів організаційних та наукових здобутків [14].

Отже, ДП «ДГ «Саливонківське» найкращим чином відповідає потребам нашого наукового пошуку.

Для початку для прогнозування банкрутства використаємо відомі зарубіжні Zмоделі, отримані результати розрахунків та їх інтерпретацію об'єднано в таблиці 1. В усіх розрахунках цієї публікації використано дані звітності ДП «ДГ «Саливонківське» за 2015-2017 роки.

Таблиия 1

Зведені дані визначення ймовірності банкрутства за моделями зарубіжних авторів

\begin{tabular}{|c|c|c|c|}
\hline \multirow{2}{*}{ Моделі } & \multicolumn{3}{|c|}{ Роки } \\
\cline { 2 - 4 } & 2015 & 2016 & 2017 \\
\hline 1 & 2 & 3 & 4 \\
\hline \multicolumn{3}{|c|}{ Модель Е.Альтмана } \\
\hline $\begin{array}{c}\mathrm{Z}_{\mathrm{A}}=0,717 \cdot \mathrm{X}_{1}+0,847 \cdot \mathrm{X}_{2}+3,107 \cdot \mathrm{X}_{3}+ \\
0,42 \cdot \mathrm{X}_{4}+0,995 \cdot \mathrm{X}_{5}\end{array}$ & 42,111 & 24,870 & 37,022 \\
\hline \multicolumn{3}{|c|}{$\begin{array}{l}\text { Перевищення граничного значення Z за даною } \\
\text { моделлю }(1,23) \text { свідчить про стійкий фінансовий } \\
\text { стан підприємства, здатність продовжувати свою } \\
\text { діяльність, тоді як менші значення вказують на } \\
\text { високу ймовірність його банкрутства. }\end{array}$} \\
\hline Знтерпретація даних & $\begin{array}{l}\text { Розрахований показник } \mathrm{Z}_{\mathrm{A}} \text { значно перевищує } \\
\text { граничне значення, що свідчить про стабільний і }\end{array}$ \\
\hline
\end{tabular}


Продовження табл. 1

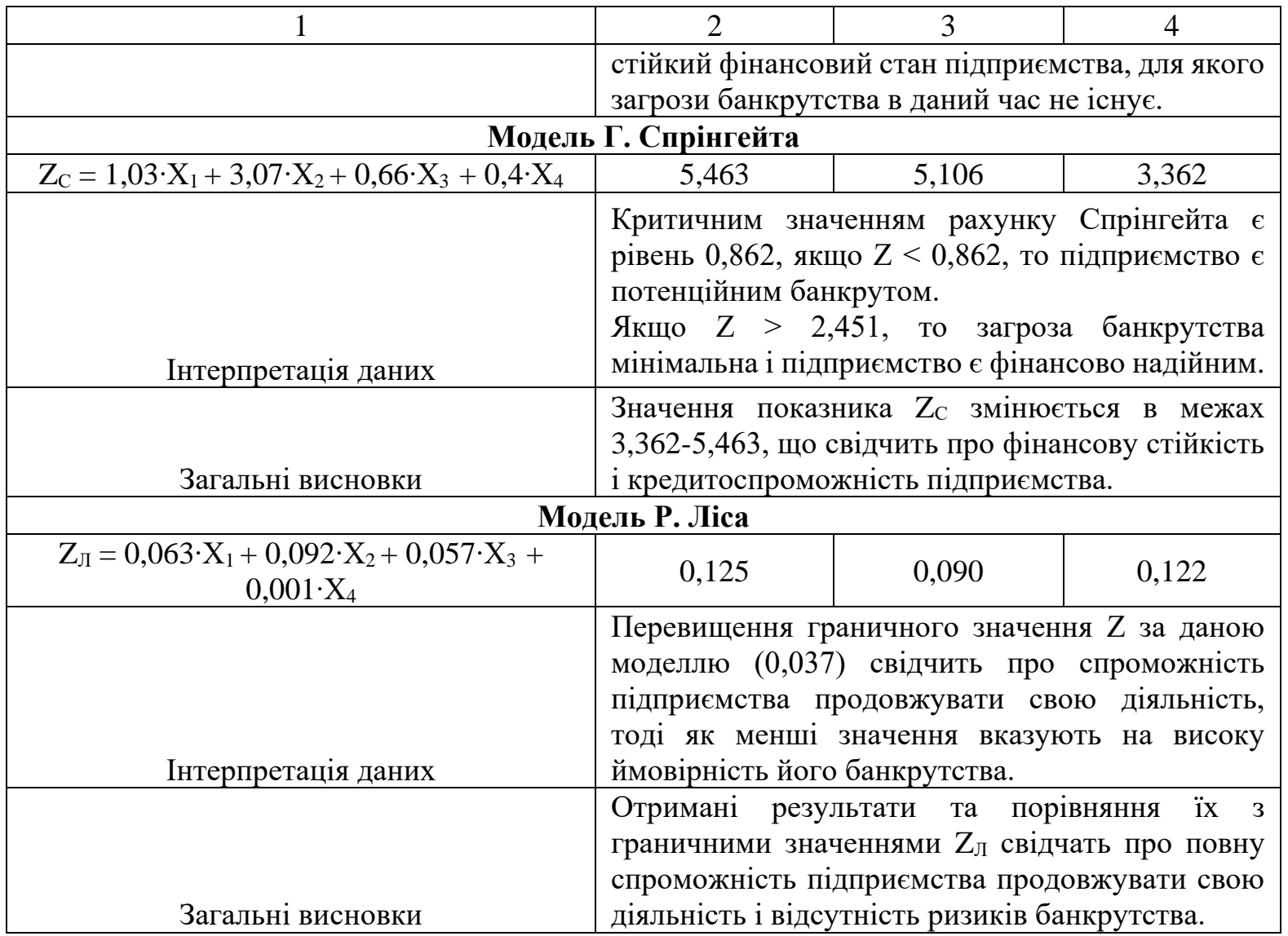

Джерело: розрахунки автора на основі звітності ДП «ДГ «Саливонківське»

Пам'ятаючи, що діагностика банкрутства підприємства здійснюється задля своєчасного виявлення перших ознак його неплатоспроможності, збитковості та фінансової залежності, зрозумілим є використання в класичних моделях діагностики банкрутства показників прибутковості, фінансової стійкості, ліквідності та платоспроможності, які найбільш системно характеризують стан ділової активності. Тому у застосованих моделях, в основному, оперують показниками операційної, інвестиційної та фінансової сфери діяльності підприємства, розглядаючи їх з різним ступенем зв'язків і взаємного впливу.

Отримані результати розрахунків та порівняння їх з граничними значеннями свідчать про повну спроможність ДП «ДГ «Саливонківське» продовжувати свою діяльність, стан фінансової благополучності і відсутність ризиків банкрутства.

Усі моделі, не дивлячись на схожі завдання, мають сутнісні особливості щодо ïх використання. Скажімо, модель Альтмана дозволяє розрахувати індекс кредитоспроможності і, як результат, віднести підприємство до потенційних банкротів чи до успішно працюючих підприємств. Альтмана у світі вважають засновником прогнозування банкрутства, за що він отримав всесвітнє визнання. Однак в основу моделі для погашення заборгованості закладена ринкова вартість акцій, що вказує на специфіку діяльності компаній, для яких вона розроблялась. Демонструючи високу точність прогнозів (для підприємств 60-х років минулого століття), модель все ж не була досконалою і на той час [2, с. 60]. 
Спрінгейт Г. запропонував власну модель прогнозування банкрутства пізніше моделі Альтмана (1978р.), маючи можливість іiі дещо удосконалити, врахувати та усунути певні недоліки. Та, незважаючи на всі переваги моделі Спрінгейта, вона також не відповідає стану та тенденціям в українській економіці, тому не дає змоги достатньо об’єктивно визначати фінансовий стан національних підприємств та ідентифікувати ризики неплатоспроможності.

Модель Р. Ліса обмежується можливістю визначення ефективності використання активів підприємства та рівня ризику його автономності, що потенційно формує умови для погашення заборгованості. Основним недоліком моделі $\epsilon$ те, що вона не передбачає аналізу структури активів по їх ліквідності, отже зробити висновки щодо реального рівня загрози неплатоспроможності важко. Крім цього, спільним недоліком цих моделей Матвійчук А.А. називає статичність визначених у них коефіцієнтів, хоча вони різко змінюються рік у рік та від країни до країни. Саме цей факт, на переконання автора, не дозволяє механічно використовувати їх для національних підприємств (табл. 2) [5, с. 20].

Таблиия 2

Система показників прогнозування банкрутства У. Бівера для діагностики ДП «ДГ «Саливонківське»

\begin{tabular}{|c|c|c|c|c|c|}
\hline \multirow[b]{2}{*}{ Показники } & \multirow[b]{2}{*}{ Формула } & \multirow[b]{2}{*}{$\begin{array}{c}\text { Розрахунок } \\
\text { показника }\end{array}$} & \multicolumn{3}{|c|}{$\begin{array}{c}\text { Значення коефіціснта Бівера за } \\
\text { міжнародними стандартами }\end{array}$} \\
\hline & & & $\begin{array}{c}\text { Стабільна } \\
\text { фірма }\end{array}$ & $\begin{array}{c}\text { За } 5 \text { років } \\
\text { до } \\
\text { банкрутст } \\
\text { ва }\end{array}$ & $\begin{array}{c}\text { За } 1 \text { рік до } \\
\text { банкрутст } \\
\text { ва }\end{array}$ \\
\hline $\begin{array}{c}\text { Коефіцієнт Бівера } \\
\text { У разі, якщо цей } \\
\text { показник не } \\
\text { перевищує 0,2, це } \\
\text { відображає небажане } \\
\text { скорочення частки } \\
\text { прибутку, яка } \\
\text { спрямовується на } \\
\text { розвиток виробництва }\end{array}$ & $\begin{array}{c}\text { КБ }=(\text { ЧП+Ам }) /(Д 3+К з) \\
\text { де ЧП - чистий прибуток; } \\
\text { АВ - амортизація; } \\
\text { Дз - довгострокові } \\
\text { зобов’язання; } \\
\text { Кз - короткострокові } \\
\text { зобов’ язання }\end{array}$ & $\begin{array}{l}2015 \text { p. } 8,132 \\
2016 \text { p. }-6,078 \\
2017 \text { p. }-5,857\end{array}$ & $0,4-0,45$ & 0,17 & $-0,15$ \\
\hline $\begin{array}{c}\text { Рентабельність } \\
\text { активів }\end{array}$ & $\begin{array}{c}\frac{4 \Pi}{A} \times 100 \%, \\
\text { де } \mathrm{A}-\text { обсяг активів }\end{array}$ & $\begin{array}{l}2015 \text { p. }-5,56 \\
2016 \text { p. }-5,34 \\
2017 \text { p. }-5,19\end{array}$ & $6-8$ & 4 & -22 \\
\hline Фінансовий леверидж & Д3 $3+\mathrm{K} 3 / \mathrm{A} * 100 \%$ & $\begin{array}{l}2015 \text { p. }-0,911 \\
2016 \text { p.- } 1,379 \\
2017 \text { p.- } 1,438\end{array}$ & $<37$ & $<50$ & $<80$ \\
\hline $\begin{array}{c}\text { Коефіцієнт покриття } \\
\text { оборотних активів } \\
\text { власним оборотним } \\
\text { капіталом }\end{array}$ & $\begin{array}{c}\text { (Вк - На) / активи, } \\
\text { де Вк - власний капітал; } \\
\text { На - необоротні активи }\end{array}$ & $\begin{array}{l}2015 \text { p. }-0,209 \\
2016 \text { p. }-0,224 \\
2017 \text { p. }-0,245\end{array}$ & 0,4 & $<0,3$ & $<0,06$ \\
\hline $\begin{array}{c}\text { Коефіцієнт покриття } \\
\text { зобов' язань }\end{array}$ & $\begin{array}{c}\mathrm{OA} / \text { Д3+К3 } \\
\text { де OA - оборотні активи }\end{array}$ & $\begin{array}{l}\text { 2015p.-23,98 } \\
\text { 2016p.-17,28 } \\
2017 \text { p. }-18,02\end{array}$ & $<3,2$ & $<2$ & $<1$ \\
\hline
\end{tabular}

Джерело: розрахунки автора на основі звітності ДП «ДГ «Саливонківське»

Досить позитивно в практиці антикризової діяльності українських підприємств оцінюється модель Бівера. Це методика експрес-аналізу, яка дозволяє виявити відхилення в структурі балансу підприємства та вжити відповідних заходів для упередження банкрутства. Отримані значення розрахунків порівнюються з їх нормативними значеннями для трьох станів підприємства, які Бівер розрахував для благополучних компаній, для компаній, збанкрутілих протягом року, і для фірм, які 


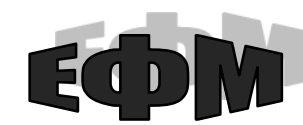

http://efm.vsau.org/

стали банкрутами протягом п’яти років. Згідно із цією методикою не передбачено розрахунку вагових коефіцієнтів для показників фінансового стану, не розраховується і підсумковий показник.

В основу оцінки за коефіцієнтами Бівера покладено відносну прибутковість діяльності підприємства, а прогнозування банкрутства базується на зниженні прибутковості стабільної фірми 3 40-45\% до 17\% (за 5 років до банкрутства). За рік до банкрутства підприємство відносно збиткове на 15\%. Якщо значення коефіцієнту Бівера не перевищує 20\%, має місце небажане скорочення частки прибутку, який використовується на розвиток та модернізацію виробництва.

Розраховані показники по ДП «ДГ «Саливонківське» свідчать про значний запас відносної прибутковості підприємства. При цьому все ж варто звернути увагу на спадну динаміку коефіцієнта Бівера.

На основі проведених розрахунків можемо зазначити, що отримані результати 3 використанням різних моделей прогнозування банкрутства стосовно ДП «ДГ «Саливонківське» не $є$ суперечливими. Показники звітності господарства не дають підстав для сумнівів - воно прибуткове (розмір валового прибутку впродовж 20152017 рр. становив 5647-11575 тис. грн), має задовільну структуру активів, практично не використовує запозичень, які можуть розбалансувати фінансовий стан. Крім того, використовувати вказані моделі не складно. Вважаємо за необхідне зазначити, що в різних моделях має місце певна невідповідність у назві деяких показників фінансового стану, які розраховуються однаково: наприклад, і власні оборотні кошти (модель Е.Альтмана), і робочий капітал (модель Г.Спрінгейта) трактуються як величина власних коштів, вкладених в оборотні активи.

Вивчення літературних джерел $з$ теми дослідження показує, що зарубіжні моделі придатні для використання в українських умовах із певними застереженнями. Усі вони мають свої переваги та недоліки, які проявляються в тій чи іншій мірі залежно від особливостей і специфіки об'єкту аналізу, його фінансово-економічного стану $[7$, с. $41 ; 13$, с. 58]. Якщо в практиці їх використання ми не можемо змінювати ні коефіцієнти, ні їх граничні значення (Матвійчук А.А. називає такі спроби безперспективними [5, с. 20]), то покладатися на результати аналізу за однією моделлю точно не варто. Рекомендується при здійсненні діагностики 3 використанням зарубіжних моделей обирати такі підходи, які давали б можливість отримати більш достовірну та точну оцінку фінансово-економічного стану. Ось чому, не дивлячись на однозначність висновків щодо ймовірності банкрутства нашого підприємства, рекомендувати апробовані моделі для основної діагностики сільськогосподарських підприємств ми не можемо.

Вітчизняна теорія і практика антикризового управління також пропонує ряд методик для оцінювання ймовірності банкрутства. Варто назвати методики Сршової Н., Матвійчука А., Терещенка О., методику оцінки платоспроможності Лігоненко Л. та Ковальчук Г., Гайворонської Ю. тощо [7, с. 41; 5, с. 20; 12, с. 323]. Безперечно, вони більшою мірою адаптовані до вітчизняних реалій та нівелюють недоліки зарубіжних моделей. В той же час, з огляду на суто індивідуальні характеристики і чинники кожного підприємства залежно від галузевої належності, організаційно-правової форми, розмірів підприємства, типу виробництва, рівня спеціалізації, концентрації та кооперації, характеристик виробничого потенціалу, наявності чи відсутності науково-технічного потенціалу, рівня розвитку управління, навіть рівня кваліфікації персоналу універсальної моделі, прогнозування банкрутства все ж не існує. 
Продовжимо вивчати можливість використання моделей прогнозування банкрутства, використовуючи адаптовані та модифіковані моделі, розроблені українськими вченими. Першу таку спробу розробити модель з використанням дискримінантного аналізу, яка була б придатною для оцінки ймовірності банкрутства на вітчизняних підприємствах, зробив відомий український дослідник сфери фінансового антикризового менеджменту Терещенко О.О. [11, с. 38]. Автор пропонує два варіанти своєї моделі - 3 використанням шести і десяти показників. Сутність розробленої моделі полягає у визначенні інтегрального показника фінансового стану підприємств. При цьому відбір показників та їх вагових коефіцієнтів в моделі базується на використанні вітчизняних статистичних даних, в той же час враховуючи сучасну міжнародну практику. Різноманітні модифікації базової моделі сприяють визначенню критичних значень показників для підприємств різних видів діяльності, тим самим враховуючи їх галузеві особливості (табл. 3).

Таблиця 3

\section{Визначення ймовірності банкрутства ДП «ДГ «Саливонківське»} за моделлю О.Терещенка

\begin{tabular}{|c|c|c|c|}
\hline \multirow{2}{*}{ Показники та порядок їх розрахунку } & \multicolumn{3}{|c|}{ Роки } \\
\hline & 2015 & 2016 & 2017 \\
\hline $\begin{array}{l}\mathrm{X}_{1}-\text { Сума грошових коштів / Сума } \\
\text { зобов'язань }\end{array}$ & 1,131 & 0,376 & 0,665 \\
\hline $\begin{array}{l}\text { Х } 2 \text { - Вартість валюти балансу / Сума } \\
\text { зобов'язань }\end{array}$ & 99,01 & 57,91 & 86,24 \\
\hline $\begin{array}{l}\mathrm{X}_{3}-\text { Сума чистого прибутку / } \\
\text { Середньорічна сума активів }\end{array}$ & 0,054 & 0,053 & 0,052 \\
\hline $\begin{array}{l}\text { Х } \\
\text { реалізації }\end{array}$ & 0,228 & 0,243 & 0,256 \\
\hline $\begin{array}{l}\text { Х }- \text { Виробничі запаси / Виручка від } \\
\text { реалізації }\end{array}$ & 0,472 & 0,336 & 0,315 \\
\hline $\begin{array}{l}\text { Х }{ }_{6} \text { - Виручка від реалізації / Валюта } \\
\text { балансу }\end{array}$ & 0,361 & 0,556 & 0,597 \\
\hline $\mathrm{Z}_{\mathrm{TEP}}$ & 11,474 & 7,103 & 9,851 \\
\hline Інтерпретація даних & \multicolumn{3}{|c|}{$\begin{array}{l}\mathrm{Z}>2 \text { - підприємство } є \text { фінансовою стійким і йому } \\
\text { не загрожує банкрутство; } \\
1<\mathrm{Z}<2 \text { - у підприємства порушено фінансову } \\
\text { рівновагу (фінансову стійкість), але йому не } \\
\text { загрожує банкрутство за умови переходу на } \\
\text { антикризове управління; } \\
0<Z<1 \text { - підприємству загрожує банкрутство, } \\
\text { якщо воно не здійснить санаційних заходів; } \\
\text { Z < } 0 \text { - підприємство є напівбанкрутом. }\end{array}$} \\
\hline
\end{tabular}

Джерело: розрахунки автора на основі звітності ДП «ДГ «Саливонківське»

Нормативне значення моделі О.О. Терещенко відповідає 2. Чим менше значення фактичного показника у порівнянні 3 нормативним, тим більший ризик банкрутства на підприємстві. Значне перевищення граничного значення $\mathrm{Z}_{\mathrm{TEP}}$ за його моделлю для наших підприємств свідчить про фінансову стійкість і спроможність ДП «ДГ «Саливонківське» продовжувати свою діяльність.

Використання моделі Терещенка О.О. видається нам більш прийнятним i надійним способом діагностики банкрутства, адже розроблялась вона 3 використанням статистичних даних вітчизняних підприємств, враховуючи 
особливості національної економіки. Звичайно, і ця модель не є досконалою, дослідники відзначають іiі слабкі сторони, як, наприклад, відсутність поглибленої класифікації стійкості фінансового стану (існує лише задовільний та незадовільний фінансовий стан); широкий інтервал невизначеності, що зобов'язує проводити додатковий аналіз для ідентифікації стійкості фінансового стану тощо $[1$, с. $58 ; 2$, с. $60 ;$, с. 20]. Однак те, що різні модифікації базової моделі Терещенка О.О. дозволяють використовувати іiі для підприємств різних видів діяльності, враховуючи їх галузеві особливості, вигідно вирізняє пі серед зарубіжних моделей, які позиціонуються, як правило, як універсальні [13, с. 58].

Таблиия 4

Визначення ймовірності банкрутства ДП «ДГ «Саливонківське» за моделлю, затвердженою Міністерством економіки України

\begin{tabular}{|c|c|c|c|}
\hline \multirow{2}{*}{ Показники та порядок їх розрахунку } & \multicolumn{3}{|c|}{ Роки } \\
\hline & 2015 & 2016 & \begin{tabular}{l|l}
2017 \\
\end{tabular} \\
\hline $\begin{array}{l}\mathrm{X}_{1}-\text { коефіцієнт покриття (оборотні активи / } \\
\text { поточні зобов'язання) }\end{array}$ & 25,40 & 18,02 & 17,28 \\
\hline $\begin{array}{l}\mathrm{X}_{2}-\text { коефіцієнт забезпечення власними } \\
\text { засобами (власний капітал - необоротні активи/ } \\
\text { оборотні активи) }\end{array}$ & 0,958 & 0,942 & 0,944 \\
\hline $\begin{array}{l}\mathrm{X}_{3}-\text { коефіцієнт оборотності активів (дохід від } \\
\text { реалізації продукції/ середньорічна вартість } \\
\text { активів) }\end{array}$ & 0,372 & 0,572 & 0,609 \\
\hline $\begin{array}{l}\mathrm{X}_{4} \text { - коефіцієнт рентабельності операційної } \\
\text { діяльності (прибуток від операційної діяльності } \\
\text { / операційні витрати) }\end{array}$ & 0,178 & 0,233 & 0,110 \\
\hline $\begin{array}{l}\mathrm{X}_{5} \text { - коефіцієнт рентабельності активів (чистий } \\
\text { прибуток / загальна вартість активів) }\end{array}$ & 0,056 & 0,053 & 0,052 \\
\hline $\begin{array}{l}\mathrm{X}_{6} \text { - коефіцієнт оборотності залученого капіталу } \\
\text { (дохід від реалізації продукції/ вартість } \\
\text { залученого капіталу) }\end{array}$ & 40,85 & 41,47 & 42,33 \\
\hline $\mathrm{Z}_{\mathrm{ME}}$ & 22,755 & 15,078 & 14,211 \\
\hline Інтерпретація даних & $\begin{array}{r}\text { Нормати } \\
\text { Hop } \\
\end{array}$ & $\begin{array}{l}\text { нення } X_{1} \\
\text { с нелікв } \\
\text { е значен }\end{array}$ & $\begin{array}{l}\text { uo } \mathrm{X}_{1}<1 \\
0,1\end{array}$ \\
\hline Джерело: розрахунки автора на основі зві & юсті ДП & иливонкі & \\
\hline $\begin{array}{l}\text { Практикують в Україні і законодав } \\
\text { впроваджені у юридичну та економіч } \\
\text { відповідальними за регулювання процесів } \\
\text { (табл. 4). Мета таких рекомендацій - забезп } \\
\text { фінансово-економічної оцінки стану підпрг } \\
\text { податкові органи використовують саме такі } \\
\text { системної кризи на підприємстві і провад } \\
\text { суб’єкта господарювання. Скористаємось од } \\
\text { Наказі Міністерства економіки України } \\
\text { виявлення ознак неплатоспроможності піді } \\
\text { банкрутства чи доведення до банкрутства» } \\
\text { 19. 01. } 2006 \text { № 81) [8]. Як і в згаданих ра }\end{array}$ & $\begin{array}{l}\text { регламє } \\
\text { практ } \\
\text { анкрутст } \\
\text { нити однс } \\
\text { мств. Як } \\
\text { делі для } \\
\text { ення спю } \\
\text { ією із таг } \\
\text { «ро ме } \\
\text { иємства } \\
\text { ід } 17.01 \\
\text { ше моде }\end{array}$ & $\begin{array}{l}\text { ні моде } \\
\text { ержавн } \\
\text { подарю } \\
\text { ий підх } \\
\text { iло, гос } \\
\text { ення ха } \\
\text { ро бан } \\
\text { делей, } \\
\text { ні рекс } \\
\text { гак дій } \\
\text { o10 зі } \\
\text { етодик: }\end{array}$ & $\begin{array}{l}\text { роблені і } \\
\text { органами, } \\
\text { суб'єктів } \\
\text { дійснення } \\
\text { ські суди, } \\
\text { них ознак } \\
\text { зо даного } \\
\text { цованою в } \\
\text { ції щодо } \\
\text { ховування } \\
\text { а доп. від } \\
\text { оозування }\end{array}$ \\
\hline
\end{tabular}


банкрутства Міністерства економіки України передбачає аналіз основних об'єктів кризової небезпеки підприємства: показники обсягу та структури капіталу як за ліквідністю активів, так і за джерелами формування, фінансових зобов'язань, формування доходів та прибутків від виробничо-господарської діяльності тощо. У той же час вона найбільш повно враховує національні особливості господарювання. Вказана модель включає в оцінку шість факторів і має такий вигляд:

$$
\mathrm{Z}_{\mathrm{ME}}=1,04 \mathrm{X}_{1}+0,75 \cdot \mathrm{X}_{2}+0,15 \cdot \mathrm{X}_{3}+0,42 \cdot \mathrm{X}_{4}+1,8 \cdot \mathrm{X}_{5}-0,06 \cdot \mathrm{X}_{6}-2,16 .
$$

Передбачені в моделі розрахунки дозволяють зрозуміти динаміку і причини змін коефіцієнтів, установити причинно-наслідкові зв’язки між показниками фінансової звітності підприємства. Наприклад, коефіцієнт покриття, хоч і дещо зменшується в динаміці, досить далекий від критичного значення, за якого баланс буде неліквідним. Так у нашому випадку на кожну гривню поточних зобов'язань приходилось 17,28 грн оборотних активів, що підтверджує платоспроможність господарства (2017р.). У фінансовій стійкості підприємства переконує коефіцієнт забезпечення власними засобами, коливання якого несуттєві.

Отриманий нами інтегрований показник $\mathrm{Z}_{\mathrm{ME}}$ вказує на низьку ймовірність банкрутства впродовж 2015-2017рр. Підприємство спроможне погашати свої боргові зобов'язання.

Проведені нами розрахунки щодо можливостей використання зарубіжних моделей прогнозування банкрутства не дозволяють виділити єдиного об'єктивного і точного підходу, який би забезпечував однозначну, достовірну, найбільш зважену оцінку фінансово-економічного стану підприємства. Зазначені моделі можна i потрібно використовувати комплексно, отримані дані перевіряти і порівнювати 3 результатами розрахунків за іншими моделями. Більш надійні і точні результати дають адаптовані і модифіковані моделі вітчизняних науковців.

Висновки. Не дивлячись на позитивну динаміку розвитку, сільськогосподарські підприємства України знаходяться у складному стані, вимушені долати численні проблеми і боротися з викликами.

Проблеми, які виникають в управлінні сільськогосподарськими підприємствами, можуть пояснюватися складною структурою галузі, несприятливим зовнішнім середовищем, низьким рівнем готовності управлінського персоналу до діяльності в умовах кризи тощо.

Наслідки криз на підприємствах, як правило, пов'язані з двома факторами: їх причинами і вжитими заходами. Процес управління має забезпечувати постійну готовність підприємств до змін і ліквідацію кризових ситуацій. У цьому сутність і об'єктивна потреба здійснювати антикризове управління як систему управлінських заходів щодо діагностики, упередження, нейтралізації і подолання кризових явищ та причин їх виникнення на всіх рівнях економіки.

Сучасна економічна наука пропонує численні розробки у сфері антикризового менеджменту підприємств, аналізу та прогнозу їх діяльності, що дає змогу виявляти ранні ознаки неплатоспроможності й оцінювати ймовірність банкрутства. Кожна модель характеризується певними перевагами та недоліками у практичному застосуванні, що виключає можливість використання єдиної універсальної моделі для вітчизняних підприємств різної галузевої належності. Ретельний вибір та комплексне використання одночасно кількох моделей, включаючи спеціально розроблені i рекомендовані для вітчизняних підприємств, дозволить значно підвищити достовірність і забезпечить максимальну точність прогнозів. Проведення 
діагностики дасть можливість вчасно виявляти небажані відхилення та попереджувати проблеми, забезпечуючи стійкий фінансовий стан, що і $є$ головною метою антикризового управління.

Не дивлячись на те, що універсальної моделі прогнозування банкрутства немає i не може бути, очевидною $є$ необхідність максимальної адаптації методик прогнозування ймовірності потрапляння підприємства в зону критичного ризику до ситуації в національній економіці, існуючих ризиків, особливостей діяльності, специфіки обліку і звітності на підприємствах України в цілому й аграрної сфери зокрема.

\section{Список використаних джерел}

1. Власюк В.С., Гордієнко К.О., Пшенична А.О. Оцінка ймовірності банкрутства вітчизняних підприємств (на прикладі ПАТ «Комбінат «Тепличний»). Економіка та управління національним господарством. 2017. № 12. С. 58-62.

2. Воронкова Т.С., Чернюк Ю.В. Сравнительная характеристика методов оценки кризисного состояния предприятий с применением формул Э. Альтмана и А.А. Терещенко. «Украина - Болгария - Европейский Союз: современное состояние и перспективы». Сборник материалов международной научно-практической конференции. Т. 1.: Херсон, ПП Вишемирский В.С. 2012. С. 60-64.

3. Державна служба статистики України: офіційний сайт [Електронний pecypc] - Режим доступу http://www.ukrstat.gov.ua.

4. Мазур В.А., Томчук О.Ф., Браніцький Ю.Ю. Методика аналізу фінансового стану підприємства відповідно до вимог внутрішніх і зовнішніх користувачів. Економіка. Фінанси. Менеджмент. Актуальні питання науки і практики. 2017. № 3. С. 7-20.

5. Матвійчук А. Діагностика банкрутства підприємств. Економіка України. 2007. № 4. С.20-28.

6. Мельниченко О.А. Антикризова політика держави: сутність та пріоритетні напрями. Розвиток системи державного управління в Україні. 2015. № 2 (49). С. 3-8.

7. Муляр Т.С. Імплементація методик та моделей діагностики кризового стану в практику аграрних підприємств. Економіка та держава. 2017. № 4. С.41-45.

8. «Про методичні рекомендації щодо виявлення ознак неплатоспроможності підприємства та ознак дій з приховування банкрутства чи доведення до банкрутства»: Наказ Міністерства економіки України від 17.01.2001 №10 зі змін. та доп. від 19.01.2006 № 81 //zakon1.rada.gov.ua.

9. Ракосій П.В. Особливості побудови механізму антикризового управління на підприємствах агропромислового комплексу. Науковий вісник Полісся. 2016. № 1 (5). C. 110-113.

10. Скібіцький О.М. Антикризовий менеджмент: Навч.посібник. К.: «Центр учбової літератури». 2009. 568 с.

11. Терещенко О. Дискримінантна модель інтегральної оцінки фінансового стану підприємства. Економіка України. 2003. № 8. С. 38-44.

12. Терещенко О.О. Антикризове фінансове управління на підприємстві: монографія. К. КНЕУ. 2004. 268 с.

13. Янковець Т.М., Чернюк Ю.В. Порівняння сучасних моделей діагностики ймовірності банкрутства підприємства: закордонний та вітчизняний досвід. Інвестиції: практика та досвід. 2016. № 20. С. 58-62. 


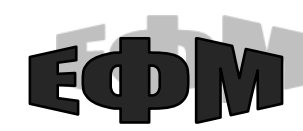

http://efm.vsau.org/

14. Сайт Вінницького Національного Аграрного Університету [Електронний peсурс]. Режим доступу: www.vsau.org/web/vsau.nsf/webgr-viev/Gr.PNF2C? Open Document\&cant=5\& RestrictToCategory=GrPNF2C.

\section{References}

1. Vlasiuk, V.Ie., \& Hordienko, K.O., \& Pshenychna, A.O. (2017). Otsinka ymovirnosti bankrutstva vitchyznianykh pidpryiemstv (na prykladi PAT «Kombinat «Teplychnyi») [Estimation of the probability of bankruptcy of domestic enterprises (on example of PJSC "Combine Works" Teplichny"]. Ekonomika ta upravlinnia natsionalnym hospodarstvom Economics and management of the national economy, 12, 58-62 [in Ukrainian].

2. Voronkova, T.Ie., \& Cherniuk, Yu.V. (2012). Sravnitelnaia kharakterystika metodov otsenky krizisnogo sostoianiia predpriiatyi s prymenenyem formul E. Altmana i A.A. Tereshchenko [Comparative characteristics of methods for assessing of the crisis state of enterprises using the formulas of E. Altman and A.A. Tereshchenko]. Collection of materials from: Mizhnarodna naukovo-praktychna konferentsiia "Ukraina-BolgariiaEvropeiskii Soiuz: sovremennoe sostoianie i perspektivy" - International scientificpractical conference "Ukraine-Bulgaria-European Union: current state and prospects", Kherson, PP Vishemirskiy V.S., pp. 60-64 [in Russian].

3. Sait derzhavnoi sluzhby statystyky Ukrainy [Site of State Statistics Service of Ukraine]. Available at: http://www.ukrstat.gov.ua [in Ukrainian].

4. Mazur, V.A., \& Tomchuk, O.F., \& Branitskyi, Yu.Yu. (2017). Metodyka analizu finansovoho stanu pidpryiemstva vidpovidno do vymoh vnutrishnikh i zovnishnikh korystuvachiv [Methodology for analyzing of the financial condition of an enterprise according to the requirements of internal and external users]. Ekonomika. Finansy. Menedzhment. Aktualni pytannia nauky i praktyky - Economy. Finances. Management. Actual issues of science and practical activity, 3, 7-20 [in Ukrainian].

5. Matviychuk, A. (2007). Diahnostyka bankrutstva pidpryiemstv [Diagnostics of bankruptcy of enterprises]. Ekonomika Ukrainy - Economy of Ukraine, 4, 20 -28 [in Ukrainian].

6. Melnychenko, O.A. (2015). Antykryzova polityka derzhavy: sutnist ta priorytetni napriamy [Anti-crisis policy of the state: essence and priority directions]. Rozvytok systemy derzhavnoho upravlinnia v Ukraini - Development of the system of public administration in Ukraine, 2(49), 3-8 [in Ukrainian].

7. Muliar, T.S. (2017). Implementatsiia metodyk ta modelei diahnostyky kryzovoho stanu $\mathrm{v}$ praktyku ahrarnykh pidpryiemstv [Implementation of methods and models of diagnostics of a crisis state in the practice of agrarian enterprises]. Ekonomika ta derzhava - Economy and the state, 4, 41-45 [in Ukrainian].

8. Nakaz Ministerstva ekonomiky Ukrainy vid 17.01.2001 №10 zi zmin. ta dop. Vid 19.01.2006 № 81 «Pro metodychni rekomendatsii shchodo vyiavlennia oznak neplatospromozhnosti pidpryiemstva ta oznak dii z prykhovuvannia bankrutstva chy dovedennia do bankrutstva» [Order of the Ministry of Economy of Ukraine dated January 17, 2001 No. 10 with amendments and additions from January 19, 2006 № 81 "About methodical recommendations for revealing signs of insolvency of the enterprise and signs of actions to conceal bankruptcy or bring to bankruptcy"]. Available at: http://zakon1.rada.gov.ua. 
9. Rakosiy, P.V. (2016). Osoblyvosti pobudovy mekhanizmu antykryzovoho upravlinnia na pidpryiemstvakh ahropromyslovoho kompleksu [Features of creation of the mechanism of crisis management at the enterprises of the agro-industrial complex]. Naukovyi visnyk Polissia - 'Scientific bulletin of Polissia, 1(5), 110-113 [in Ukrainian].

10. Skibitskyi, O.M. (2009). Antykryzovyi menedzhment [Anti-crisis management]. Kyiv, Tsentr uchbovoi literatury [in Ukrainian].

11. Tereshchenko, O (2003). Dyskryminantna model intehralnoi otsinky finansovoho stanu pidpryiemstva [Discriminant model of the integrated assessment of the financial condition of the enterprise]. Economika Ukrainy - Economy of Ukraine, 8, 38-44 [in Ukrainian].

12. Tereshchenko, O.O. (2004). Antykryzove finansove upravlinnia na pidpryiemstvi [Anticrisis financial management at the enterprise]. Kyiv, KNEU [in Ukrainian].

13. Yankovets, T.M., \& Cherniuk, Yu.V. (2016). Porivniannia suchasnykh modelei diahnostyky ymovirnosti bankrutstva pidpryiemstva: zakordonnyi ta vitchyznianyi dosvid [Comparison of modern models for diagnosing of the probability of bankruptcy of an enterprise: foreign and native experience]. Investytsii: praktyka ta dosvid - Investments: practice and experience, 20, 58-62 [in Ukrainian].

14. Sait Vinnytskogo Natsionalnogo Agrarnogo Universytetu [Site of Vinnytsia National Agrarian University]. Available at: www.vsau.org/web/vsau.nsf/webgrviev/Gr.PNF2C?OpenDocument\&cant=5\& RestrictToCategory=GrPNF2C [in Ukrainian].

\section{Відомості про автора}

ФІЩУК Наталія Юріївна - кандидат сільськогосподарських наук, доцент кафедри аграрного менеджменту, Вінницький національний аграрний університет (21008, м. Вінниця, вул. Сонячна, 3, e-mail: natalfis2016@gmail.com).

FISHCHUK Natalia - Candidate of Agricultural Sciences, Associate Professor of the Department of Agrarian Management, Vinnytsia National Agrarian University (21008, Vinnytsia, 3 Sonyachna Str., e-mail: natalfis2016@gmail.com).

ФИЩУК Наталия Юрьевна - кандидат сельскохозяйственных наук, доцент кафедры аграрного менеджмента, Винницкий национальный аграрный университет (21008, г. Винница, ул. Солнечная, 3, e-mail: natalfis2016@gmail.com). 